\author{
Michat HuCAE \\ Christian Theological Academy in Warsaw, Poland \\ (D) https://orcid.org/0000-0001-8446-0570
}

\title{
Challenges Related to the Increase in Religious Diversity in the Light of the Judicial Decisions of the European Court of Human Rights
}

\begin{abstract}
European states responded in different ways to tensions related to the increase in religious diversity, and the restrictions introduced were considered appropriate when they resulted from public security and the need to protect others, especially if the state presented a credible justification. On this occasion, the case-law of the ECHR developed two key concepts for the determination of the presence of religious symbols in public places: a powerful external symbol and an essentially passive symbol. An important achievement of the Tribunal is also the introduction of the concept of "improper proselytism." Certainly, a further increase in religious diversity in Europe may lead to new areas of controversy, which will then be assessed by the ECHR. However, the existing instruments used by the Court, such as the idea of the Convention as a living document, the theory of the margin of appreciation or the analysis of the existence of the European consensus, enable it to develop its interpretation in this regard.
\end{abstract}

Keywords: the European Court of Human Rights, religious diversity, religious symbol, proselytism

Religious diversity has challenged the legislation of many European countries for centuries. On the one hand, it was seen as an opportunity for faster economic development (e.g. Protestant settlement in Poland or Russia), or as humanitarian aid (e.g. in the case of Huguenots in Protestant countries). On the other hand, it violated the religious status quo in a given area, sometimes arousing a sense of threat or reluctance due to the very fact of being different. Currently, in Europe, religious diver- 
sity is progressing mainly due to migration, and then due to a quantitative increase resulting from the statistically higher fertility rate of Muslim communities. In the case of post-communist countries, an additional or rather marginal element is the emergence of non-traditional religious denominations. Currently, the legal actions of state authorities in this area are subject to assessment by the European Court of Human Rights, that is, by the body of the Convention for the Protection of Human Rights and Fundamental Freedoms (Journal of Laws 1993, No. 61, item 284), signed in Rome on 4.11.1950 in order to "promote and uphold the ideals and values of a democratic society." ${ }^{1}$ Complaints about violations of human rights may be brought due to the interference by a party to the convention, including in the sphere of freedom of conscience and religion (Art. 9) or the prohibition of discrimination on grounds of religion (Art. 14 in conjunction with Art. 9).

Religious diversity in the opinion of the Court of Human Rights

The European Court of Human Rights has repeatedly referred to freedom of conscience and religion as "one of the foundations of a democratic society," perceiving its great value also for "atheists, agnostics, skeptics and the indifferent," as well as the indispensability of the principle of pluralism, "acquired dearly over the centuries," as foundations of democracy. ${ }^{2}$ The Court also pointed out that "true religious pluralism [...] is critical to the survival of a democratic society,"3 adding that "pluralism, tolerance and open-mindedness are features of a democratic society," because "although individual interests must sometimes be subordinate to the group, democracy does not simply mean that the views of the majority must always prevail: a balance must be struck that ensures the proper treatment of the minority and prevents the abuse of the dominant

${ }^{1}$ Church of Scientology Moscow v. Russia, No. 18147/02, ECHR judgment of 5.04.2007, § 74 .

${ }^{2}$ Kokkinakis v. Greece, No. 14307/88, ECHR judgment of 25.05.1993, § 31; Jehovah's Witnesses of Moscow v. Russia, No. 302/02, ECHR judgment of 10.6.2010, §99.

${ }^{3}$ Leyla Sahin v. Turkey [GC], No. 44774/98, ECHR judgment of 10.11.2005, § 108; Manoussakis and Others v. Greece, No. 18748/91, ECHR judgment of 26.09.1996, § 44; 97 Members of the Gladani Congregation of Jehovah's Witnesses and 4 Others v. Georgia, No. 71156/01, ECHR judgment of 3.05.2007, § 130 and Casado Coca v. Spain, No. 15450/89, ECHR judgment of 24.02.1994, § 55 . 
position." 4 Therefore, the Court considers that "pluralism and democracy must also be based on dialogue and a spirit of compromise necessarily requiring various concessions to individuals or groups of such persons who are justified in order to uphold and promote the ideals and values of a democratic society." 5

Freedom of conscience and religion has been defined as "freedom to manifest independently and privately as well as in communion with others, publicly and in a circle sharing one faith. Art. 9 lists various forms that the manifestation of religion (denomination) or belief may take, such as service, teaching, practicing or maintaining customs." 6

However, Article 9 "does not protect every act motivated or inspired by religion or belief," because "in democratic societies where several religions coexist among the same population, it is necessary to establish restrictions for the manifestation of religion or beliefs in order to reconcile the interests of different groups and ensure that everyone's beliefs may be respected." In view of this the Court appreciates "the role of the state as a neutral and impartial regulator of conditions in which religion and religious beliefs are professed" in order to ensure public order, religious harmony and tolerance in a democratic society. ${ }^{9}$ The state should seek to ensure mutual tolerance between opposing religious groups, ${ }^{10}$ but it cannot assess the "validity of religious beliefs or the ways in which they are expressed." 11 More precisely, "the role of the authorities in such circumstances is not to remove the cause of tensions by eliminating pluralism, but to ensure mutual tolerance between opposing groups." 12 This sometimes means the need to limit the rights of some people in order to

${ }^{4}$ Leyla Sahin v. Turkey [GC]..., § 108; Chassagnou and Others v. France [GC], no. 25088/94, 28331/95 and 28443/95, ECHR judgment of 29.04.1999, § 112 .

${ }^{5}$ Leyla Sahin v. Turkey [GC]...., § 108 in fine.

${ }^{6}$ Ibidem, $\$ 105$.

7 Ibidem, § 105 in fine; also: Kalaç v. Turkey, No. 20704/92, ECHR judgment of 23.06.1997, § 27, Arrowsmith v. The United Kingdom No. 7050/75, Commission report of 12.10.1978; C. v. The United Kingdom, no. 10358/83, Commission decision of 15.12.1983 and Tepeli and Others $v$. Turkey (dec.), No. 31876/96, decision on the admissibility of the complaint of 11/9/2001, § 47; Hasan and Chaush v. Bulgaria [GC], No. 30985/96, ECHR judgment of 26.10.2000, $§ 78$; Refah Partisi (The Welfare Party) and Others $v$. Turkey [GC], No. 41340/98, 41342/98 and 41244/98, ECHR judgment of 13.02.2003., §91.

${ }^{8}$ Leyla Sahin $v$. Turkey [GC]..., § 105 in fine

9 Ibidem, § 107; also: Refah Partisi and Others v. Turkey..., § 51; 97 Members..., $\S 131$ and many others.

${ }^{10}$ United Communist Party of Turkey and Others v. Turkey [GC], No. 133/1996/752/951 ECHR judgment of 30.01.1998, §57.

${ }^{11}$ Leyla Sahin v. Turkey [GC]..., § 107.

12 Ibidem; Serif v Greece, no. 38178/97, ECHR judgment of 14.12.1999, §53. 
legitimately protect the rights of others. ${ }^{13}$ In the judicial decisions of the ECHR, decisions regarding the admissibility of such limitations or omissions by the state appeared in relation to several issues:

1) the presence of Muslim religious symbols in public space;

2) the admissibility of proselytism;

3) the involvement of foreigners in mission work;

4) the protection of religious minorities from aggression by other religious groups or foreign states in the event of deportation.

\section{Presence of religious symbols}

Regulations concerning the presence of religious symbols in the 21st century turned out to be one of the most common areas of ECHR's judicial decisions. This occurred most often with regard to restrictions on female Muslim attire in public places, including in the judgments Dahlab v. Switzerland, Leyla Şahin v. Turkey, ${ }^{14}$ and Dogru v. France..$^{15}$ The case of Dahlab v. Switzerland was an occasion for the Court to introduce the concept of "a powerful religious symbol." Such a symbol, due to its visibility, ease of identification with a specific religion and linking to the hierarchical position of a given person (e.g. when worn by a teacher or judge) "has a kind of proselytical effect," 16 which forces other people to adopt certain religious views (e.g. a specific reception of the Koran by female students), or it may lead to a conflict with other values - the prohibition of discrimination (e.g. the principle of sexual equality). For example, in the case of Leyla Şahin v. Turkey the claimant was a Muslim female, who challenged the prohibition of the use of Muslim headscarves during academic classes and exams. It was crucial for the decision by the ECHR to take into account the model of denominational law applicable in Turkey, that is, the constitutional principle of secularism of the state, resulting in the creation of a "religion-free space in which all citizens will be guaranteed equality regardless of religion." 17 National courts have found that wearing a Muslim headscarf may lead to discrimination against non-practicing

${ }^{13}$ Leyla Sahin v. Turkey [GC]..., § 108 in fine.

${ }^{14}$ Leyla Sahin v. Turkey, No. 44774/98, ECHR judgment of 29.06.2004 and Leyla

Sahin v. Turkey [GC], no. 44774/98, Grand Chamber judgment of 10.11.2005.

${ }_{15}$ Dogru v. France, No. 27058/05, judgment of the ECHR of 4.12.2008.

${ }_{16}$ Dahlab v Switzerland..., p. 9.

${ }^{17}$ Leyla Sahin v. Turkey [GC]..., § 29. 
Muslims or non-believers on the grounds that they are a minority. ${ }^{18}$ In its judgement, the ECHR drew attention to the difficulty of reconciling the Koran with the principle of sexual equality, as well as the principle of secularism in Turkey, ${ }^{19}$ which supports the protection of human rights, including "protecting students who do not practice this religion or belong to a different religion against pressure on the part of fundamentalist religious movements." ${ }^{20}$ Similarly, in March 2010 the complaint was found inadmissible in the case of El Morsli v. France, ${ }^{21}$ in which the female Muslim claimant refused to remove her Muslim headscarf during identity verification by male personnel from the French Consulate General in Marrakesh. In this case, the inadmissibility of the complaint was related to the court's belief that this requirement was for security reasons.

In the case of Dogru v. France (similar to the case of Kervanci $v$. France ${ }^{22}$ ), the female claimant was expelled from the public school due to her failure to comply, despite repeated requests to comply with the school regulations, which required appropriate clothing for PE lessons, including not wearing a headwear, as well as a confrontational approach to this situation. The Court ruled that the French state did not breach the Convention and that the prohibition of wearing religious symbols or clothes may be justified by the aim of protecting the rights and freedoms of others and maintaining public order. ${ }^{23}$ The decision in the case of Dogru v. France was used to reject another six similar cases concerning Muslim scarves (kershif) or Sikh turban (keski): Aktas v. France, ${ }^{24}$ Bayrak v. France, ${ }^{25}$ Gamaleddyn v. France, ${ }^{26}$ Ghazal v. France, ${ }^{27} \mathrm{~J}$. Singh v. France, ${ }^{28}$

18 Ibidem, $\$ 36$.

19 Cf. J. FALSKI: “Zderzenie państwa świeckiego z państwem wyznaniowym. Turecki spór o laickość." In: Państwo wyznaniowe. Doktryna, prawo i praktyka. Ed. J. SzymaneK. Warsaw 2011, p. 128.

${ }^{20}$ Leyla Sahin v. Turkey [GC] ..., in fine; similar to Refah Partisi and Others..., § 95.

${ }^{21}$ El Morsli v. France, No. 15585/06, decision on the admissibility of the complaint of 4.03.2008.

${ }^{22}$ Kervanci v. France, No. 31645/04, judgment of the ECHR of 4.12.2008.

${ }^{23}$ Ibidem, $\$ 60$.

${ }^{24}$ Aktas v. France, No. 43563/08, decision on the admissibility of the complaint of 30.06.2009.

${ }^{25}$ Bayrak v. France, No. 14308/08, decision on the admissibility of the complaint of 30.06.2009.

${ }^{26}$ Gamaleddyn v. France, No.18527/08, decision on the admissibility of the complaint of 30.06.2009.

27 Ghazal v. France, No. 29134/08, decision on the admissibility of the complaint of 30.06.2009.

${ }^{28} \mathrm{~J}$. Singh v. France, No. $25463 / 08$, decision on the admissibility of the complaint of 30.06.2009. 
and R. Singh v. France. ${ }^{29}$ The subject of the judicial decisions of the European Court of Human Rights was also the Belgian law prohibiting the use of face-covering clothing in public places for reasons of public safety. The Muslim claimants considered that this provision was against them. However, in cases Belcacemi and Oussar v Belgium ${ }^{30}$ and Dakir v. Belgium ${ }^{31}$ the Court found that the provisions were not formulated in a discriminatory manner.

The judicial decisions of the ECHR become more and more nuanced with regard to Muslim attire. In the light of the latest judgments Lachiri v. Belgium of 18 September $2018^{32}$ and Hamidović v. Bosnia and Herzegovina $^{33}$ of 5 December 2017, it can be concluded that the assessment of the admissibility of prohibiting their use in public places depends on the role of a given person (e.g. whether he or she is a person performing public functions), the nature of his or her presence (e.g. whether his or her presence is of a secondary nature), the degree of accessibility of a public place (e.g. the courtroom was found to be less public than a street or school) and the behaviour of that person. In the cases concerned, it was found that not allowing a family member of the defendant to enter the courtroom on account of hijab or to impose a penalty on the accused who refused to remove his religious headwear was in breach of Article 9 of the Convention.

However, the Court still has not addressed the legality of the Swiss prohibition on building minarets. The prohibition was introduced as a result of a referendum in 2009. Admittedly, an action against this provision was immediately brought in the cases of Ouardiri v. Switzerland ${ }^{34}$ and Ligue des Musulmans de Suisse and Others v. Switzerland, ${ }^{35}$ where the claimants were, respectively, the spokesman of the Geneva mosque and three associations and foundations in Switzerland dealing with the provision of social and spiritual assistance to Muslims, the complaints were declared inadmissible on the grounds that the claimants could not be regarded as aggrieved and therefore the merits of the case were not resolved.

The known case of Lautsi $v$. Italy, referring to the presence of the crucifix in the public space, and therefore going beyond the issue of

${ }^{29}$ R. Singh v. France, No. 27561/08, decision on the admissibility of the complaint of 30.06.2009.

${ }^{30}$ Belcacemi and Oussar v Belgium, No. 37798/13, ECHR judgment of 11.07.2017.

${ }^{31}$ Dakir v. Belgium, No. 4619/12, ECHR judgment of 11.07.2017.

${ }^{32}$ Lachiri v. Belgium, No. 3413/09, ECHR judgment of 18.09.2018.

${ }^{33}$ Hamidović v. Bosnia and Herzegovina, No. 57792/15, ECHR judgment of 5.12.2017.

${ }^{34}$ Ouardiri v. Switzerland, No. 65840/09, decision on the admissibility of the complaint of 8.07.2011.

${ }_{35}$ Ligue des Musulmans de Suisse and Others v. Switzerland, No. 66274/09, decision on the admissibility of the complaint of 8.07.2011. 
increasing religious diversity, taken up in this article, after the final sentence of the Grand Chamber, confirmed the findings set out in the above cases, emphasising the importance of the strength of the impact of a religious sign, that is, its proselytising nature as well as leading to sexual discrimination. In the case of Christian symbols, such risk seems to be definitely limited. The Grand Chamber disagreed with the Chamber's earlier judgment, which held that a crucifix hanging on a wall, due to its noticeability, should be classified as powerful external symbol. ${ }^{36}$

\section{The admissibility of proselytism}

Rationalism, as along with the personalistic and irenistic trends in Christian community, influenced the abolition of the criminality of conversion as well as proselytism in the 19th and 20th centuries in Europe. It was also influenced by the stabilisation of interfaith relations due to the lack of strong proselytic tendencies in contemporary Christianity. However, increasing religious diversity in Europe increases the probability of such practices both by Muslim community and by new religious movements, especially in the event of a significant increase in their number. In such a situation, there may be social pressure to protect against aggressive proselytism, which was already the subject of the judicial decisions of the ECHR in the case Kokkinakis v. Greece of 25 May $1993^{37}$ concerning a Jehovah's Witness repeatedly punished for proselytising. The Court indicated in its judgment that freedom of conscience and religion also includes the "right to try to persuade" other persons, ${ }^{38}$ finding that the possibility of restricting this freedom is permissible when it is necessary to reconcile the interests of various groups and to ensure respect for the views of all. The Court also found that, in principle, the prohibition of proselytism falls within such definition, especially if the purpose of the prohibition is "to protect the beliefs of others against actions that undermine their dignity and identity." 39 Interestingly, the Court relied on the documents of the World Council of Churches, indicating that proselytism may "take the form of activities consisting in offering material or

${ }^{36}$ Cf. M. Kowalski: "Symbole religijne w przestrzeni publicznej - w poszukiwaniu standardów europejskich." In: Prawne granice wolności sumienia i wyznania. Eds. R. Wieruszewski, M. Wyrzykowski, L. KondratieWa-Bryzik. Warsaw 2012, p. 63.

${ }^{37}$ Kokkinakis v. Greece, No. 14307/88, ECHR judgment of 25.05.1993.

38 Ibidem, § 31.

39 Ibidem, § 34 . 
social benefits in order to attract new members to the Church or exerting improper pressure on people in poverty or need; it may even involve the use of force or brainwashing." 40 Such actions are not protected by the Convention, and therefore the penalisation of inappropriate proselytism understood in this way is possible and even desirable. ${ }^{41}$ The jurisprudence regarding proselytism was confirmed by the Court in 1998 alongside the case of Larissis and Others $v$. Greece, ${ }^{42}$ in which the claimants were Pentecostalists serving as military air force officers. It was then found that the claimants had used the subordination to a unit's chain of command relationship for religious purposes, which constituted the so-called wrong proselytism.

\section{Religious activities of foreigners}

The rights of foreign missionaries were also a specific issue decided by the ECHR. Human rights are granted regardless of state affiliation; in particular, a foreigner has the right to manifest his or her religious beliefs, in accordance with Article 9 of the Convention, while in the territory of a country. However, they are not guaranteed the right of entry, permission to take up employment or permanent residence in a country in order to carry out a religious mission, as was decided in cases before the ECHR in the context of Christian missionaries in Turkey, Muslim imams in European countries or new religious movements in post-Communist countries. In particular, on the basis of the Convention, a foreigner does not have the right to obtain a residence permit in connection with his appointment to a clerical post in a given country, and this status does not protect him, in principle, against expulsion if there are appropriate grounds for it. This was already confirmed in the 1980s by the decision in the case of Swami Omkarananda and Divine Light Zentrum v. Switzerland, in which the claimant had used a Hindu house of prayer for criminal activities. ${ }^{43}$

It is, however, a violation of Article 9 of the Convention to prevent the entry or expulsion of a foreigner on the sole ground that he is manifesting

${ }^{40}$ Ibidem, $\$ 48$.

${ }^{41}$ Ibidem, $\$ 48$ in fine.

${ }^{42}$ Larissis and Others $v$. Greece, No. 23372/94, 26377/94 and 26378/94, judgement of 24.2.1998.

${ }^{43}$ Cf. Swami Omkarananda and Divine Light Zentrum v. Switzerland, no. 8118/77, decision on the admissibility of the complaint of 19.03.1981, where the claimant was deported for combining religious beliefs with criminal activity. 
his religion, including through missionary activity, when those religious beliefs cannot be alleged to be unworthy of protection. Some of the key cases of this type were: Perry v. Latvia ${ }^{44}$ and Nolan and K. v. Russia. ${ }^{45}$ In the first case, an Evangelical pastor was denied residency in Latvia due to the authorities' finding that he was an activist of a totalitarian or terrorist organisation and a member of a secret anti-state organisation. In the second case, Russia denied re-entry to the country to an American citizen, a missionary of a legally operating Unification Church (the socalled Moon movement) in connection with internal instructions to combat a threat to national heritage. ${ }^{46}$ The failure of both Russia and Latvia to indicate the missionaries' specific actions justifying such a restriction on their freedom led the Court to conclude that the expulsion was solely on account of their religion, and thus that there had been an unauthorised violation of Article 9.47

Similarly, in the case of Al-Nashif v. Bulgaria ${ }^{48}$ the ECHR found noncompliant with the Convention the withdrawal by the Bulgarian authorities of a permanent residence permit from the claimant, a Palestinian Muslim cleric lawfully certified by the Supreme Muslim Council and the Grand Mufti of Bulgaria, and his subsequent expulsion from the country for alleged religious extremist activities endangering state security. The Court found that the authorities' arguments for declaring the claimant a dangerous religious extremist were of very dubious value, being limited to the incorrect statement that he had taught the Koran to a group of children without legal situation and that the extremist organisations with which he was alleged to be associated were operating legally in Bulgaria and the authorities had not brought any criminal charges against their representatives. ${ }^{49}$ Nor does acting as a cleric automatically guarantee the right to prolongation of residence or employment in the territory in the light of the cases $\ddot{O} z$ v. Germany ${ }^{50}$ and El Majjaoui and Stichting Touba Moskee v. the Netherlands. ${ }^{51}$ Both cases concerned imams. The latter case is interesting in that the mosque's failure to show that it had exhausted the possibility of finding a suitable imam with a European passport was considered a legitimate reason. An exception to these negative decisions for

${ }^{44}$ Perry v. Latvia, no. 30273/03, ECHR judgment of 8.11.2007.

${ }^{45}$ Nolan and K. v. Russia, no. 2512/04, ECHR judgment of 12.02.2009.

${ }^{46}$ Nolan and K. v. Russia, § 12 and 39.

47 Ibidem, § 75; Perry v. Latvia, § 51.

${ }_{48}$ Al-Nashif v. Bulgaria, no. 50963/99, ECHR judgment of 20.06.2002.

${ }^{49}$ Ibidem, $\S \S 48$ and 58; cf. similar Bulgarian actions against Jehovah's Witnesses: Lotter and Lotter v. Bulgaria, no. 39015/97, ECHR judgment of 19.05.2004.

50 Öz v. Germany, no. 32168/96, ECHR decision of 3.12.1996.

${ }^{51}$ El Majjaoui and Stichting Touba Moskee v. the Netherlands, no. 25525/03, ECHR judgment of 20.12.2007. 
the complainants was the case of Jehovas Zeugen in Österreich v. Austria, ${ }^{52}$ where the reason for the recognition of the complaint was the differentiation of the rights of recognised and unrecognised religious associations, which was found to be discrimination under Article 14.

\section{Protection of religious minorities by the state}

According to the Convention, states have a positive obligation to act as regulators of the exercise of freedom of conscience and religion in order to defend persons under their jurisdiction against the actions of third parties. A key ruling in this regard came in the case of 97 Members of the Gladani Congregation of Jehovah's Witnesses and 4 Others v. Georgia, ${ }^{53}$ in which Jehovah's Witnesses from Georgia were victims of a violent religious assault during a religious meeting in their congregation's building. The notified security authorities did not assist Jehovah's Witnesses, and the attackers were not charged. ${ }^{54}$ The Court concluded that "the claimants $[. .$.$] faced total indifference and inaction on the part of the pub-$ lic authorities who, because of the claimants' membership of a religious community considered a threat to Christian orthodoxy, failed to act on their complaints. Deprived of means of enforcing their rights, the claimants were unable to seek protection of their freedom of conscience and religion before the national courts." ${ }_{55}$ The judges recalled that "in the name of freedom of religion, improper pressure cannot be put on others to promote one's religious beliefs. [...] The role of the State is to aid public order, religious harmony and tolerance in a democratic society." 56 In the light of events, it was noted that "by their inaction, the relevant authorities had failed in their duty to take the necessary measures to ensure that a group of orthodox extremists [...] tolerated the existence of the claimants' religious community and allowed them to freely exercise their right to freedom of religion." ${ }^{57}$ A similar decision was reached

52 Jehovas Zeugen in Österreich v. Austria, no. 27540/05, ECHR judgment of 25.09.2012.

5397 Members of the Gladani Congregation of Jehovah's Witnesses and 4 Others $v$. Georgia, no. 71156/01, ECHR judgment of 3.5.2007.

${ }^{54}$ Ibidem, § $115-116$.

55 Ibidem, $\$ 133$.

5697 Members..., § 132; cf. also Larissis and Others v. Greece..., § 54 and 59; Serif v. Greece...., §53 and Refah Partisi and Others v. Turkey..., § 91.

5797 Members..., § 134-135. 
in a case against Serbia in relation to attacks on a follower of Hare Krishna. ${ }^{58}$

Significantly, the positive obligations of the State also extend to ensuring that persons deprived of their liberty are able to practice different religions. Increasing religious diversity in prisons due to the incarceration or conversion of inmates following religions with specific dietary requirements (e.g. Islam, Eastern religions) must be adequately taken into account by the penitentiary authorities, even if it results in additional costs for the functioning of the prison system. An example of such a case was Jakóbski v. Poland ${ }^{59}$ involving a convert to Buddhism who followed the Mahayan dietary principles, which he believed excluded the consumption of meat. ${ }^{60}$ The Polish authorities unsuccessfully argued that Buddhism does not require adherence to such a rule, using only the Great PWN Encyclopedia and the online Wikipedia (sic!). The Court emphasised that dietary requirements may constitute a manifestation of religious beliefs, and had no doubt that the claimant's vegetarianism was related to the requirements of his well-known religion. ${ }^{61}$

Another obligation of the parties to the Convention is to refrain from deporting illegal immigrants to states where they face the death penalty or inhuman treatment because of their religious beliefs. This is related primarily to the right to life (Article 2 of the Convention) and Article 3 (prohibition of torture), ${ }^{62}$ and in later case law has also been extended to the right to a court and a fair trial (Article 6) and the rights to liberty and security (Article 5).

\section{Conclusions}

In conclusion, European states have reacted in different ways to the tensions associated with increased religious diversity, whereby restrictions have been deemed legitimate when based on public safety and the need to protect others, especially if the state provides a credible justification. The jurisprudence of the ECHR has on this occasion developed two concepts that are key to resolving the presence of religious symbols in public places:

\footnotetext{
${ }^{58}$ Milanović v. Serbia, no. 44614/07, ECHR judgment of 14.12.2010, § 89.

${ }^{59}$ Jakóbski v. Poland, no. 18429/06, ECHR judgment of 7.12.2010 r.

${ }^{60}$ Ibidem, § 6-7.

${ }^{61}$ Ibidem, $\$ 45$.

${ }^{62}$ Cf. A. v. Switzerland, No. 60342/16, ECHR sentence of 19.12.2017.
} 
1) a powerful external symbol;

2) an essentially passive symbol.

These terms are used depending on the recognition of the strength of the impact on third parties, particularly minors or persons dependent on the state. There is an obligation on the contracting parties to protect third parties from strong external symbols. In practice, Muslim outfits, due to differences in civilisation, are seen by the ECHR as posing a threat to the assertion of their Convention rights by vulnerable persons due to the discriminatory and authoritarian nature of Islam's mainstream. At the same time, however, relevant to the legitimacy test remains the wide margin of assessment available to the state due to cultural-religious differences and the lack of European consensus in this area. ${ }^{63}$

An important achievement of the Court is also the introduction of the concept of "improper proselytism." As K. Warchałowski points out, "the promotion of religious doctrine or other views by individuals as well as churches and other religious organizations should be done in a positive way without demeaning other religions or beliefs and taking advantage of a stronger position in interpersonal relations." ${ }^{44}$ However, in his commentary L. Garlicki emphasises that "it is a positive duty of the public authorities to allow religious assemblies to take place peacefully and to ensure their protection against violence and attacks by religious extremists." 65 The protection of freedom of conscience and religion cannot be limited due to economic aspects or a small group of believers. The importance of the positive involvement of European states in the protection of this freedom is also shown by the cases before the ECHR concerning the expulsion of Christian converts from Islam to Muslim countries, where such conversion is punishable by imprisonment or death. ${ }^{66}$ Certainly, further expansion of religious diversity in Europe may lead to new areas of controversy, subsequently assessed by the ECHR. Nonetheless, the existing instruments used by the Court, for instance, the idea of the Convention as a living document, the theory of the margin of assessment or the analysis of the existence of a European consensus enable it to develop its interpretation in this area.

${ }^{63}$ M. Hucal: Wolność sumienia $i$ wyznania w orzecznictwie ETPCz. Warsaw 2012, pp. $104-123$.

${ }^{64}$ K. Warchalowski: Prawo do wolności myśli, sumienia i religii $w$ Europejskiej Konwencji Praw Człowieka i Podstawowych Wolności. Lublin 2004, p. 119.

${ }^{65}$ L. Garlicki: Konwencja o Ochronie Praw Człowieka i Podstawowych Wolności. Warsaw 2011, t. 1, p. 567.

${ }^{66} \mathrm{Cf}$. the thoroughness of the analysis performed in the case of such a claimant's argument: F. H. v. Sweden, no. 32621/06, ECHR judgment of 20.01.2009, § 66-67 and 97. 
Bibliography

\section{ECHR judgments and decisions}

97 Members of the Gladani Congregation of Jehovah's Witnesses and 4 Others $v$. Georgia, No. 71156/01, Chamber judgment of 3.05.2007.

Aktas v. France, No. 43563/08, decision on the admissibility of the complaint of 30.06.2009.

Al-Nashif v. Bulgaria, no. 50963/99, ECHR judgment of 20.6.2002.

Arrowsmith v. The United Kingdom, No. 7050/75, Commission report of 12.10.1978.

Bayrak v. France, No. 14308/08, decision on the admissibility of the complaint of 30.06.2009.

Belcacemi and Oussar v. Belgium, No. 37798/13, ECHR judgment of 11.07.2017.

C. v. The United Kingdom, no. 10358/83, Commission decision of 15.12.1983.

Casado Coca v. Spain, No. 15450/89, ECHR judgment of 24.02.1994.

Chassagnou and Others v. France [GC], No. 25088/94, 28331/95 and 28443/95, ECHR judgment of 29.04.1999.

Church of Scientology Moscow v. Russia, No. 18147/02, ECHR judgment of 5.04.2007.

Dakir v. Belgium, No. 4619/12, ECHR judgment of 11.07.2017.

Dogru v. France, No. 27058/05, judgment of the ECHR of 4.12.2008.

El Majjaoui and Stichting Touba Moskee v. the Netherlands, No. 25525/03, ECHR judgment of 20.12.2007.

El Morsli v. France, No. 15585/06, decision on the admissibility of the complaint of 4.03.2008.

F. H. v. Sweden, No. 32621/06, ECHR judgment of 20.01.2009.

Gamaleddyn v. France, No.18527/08, decision on the admissibility of the complaint of 30.06.2009.

Ghazal v. France, No. 29134/08, decision on the admissibility of the complaint of 30.06.2009.

Hamidović v. Bosnia and Herzegovina, No. 57792/15, ECHR judgment of 5.12.2017.

Hasan and Chaush v. Bulgaria [GC], No. 30985/96, ECHR judgment of 26.10.2000.

J. Singh v. France, No. 25463/08, decision on the admissibility of the complaint of 30.06.2009.

Jakóbski v. Poland, No. 18429/06, ECHR judgment of 7.12.2010 r.

Jehovah's Witnesses of Moscow v. Russia, No. 302/02, ECHR judgment of 10.06.2010.

Jehovas Zeugen in Österreich v. Austria, No. 27540/05, ECHR judgment of 25.09.2012.

Kalaç v. Turkey, No. 20704/92, ECHR judgment of 23.06.1997.

Kervanci v. France, No. 31645/04, ECHR judgment of 4.12.2008.

Kokkinakis v. Greece, No. 14307/88, ECHR judgment of 25.05.1993. 
Lachiri v. Belgium, No. 3413/09, ECHR judgment of 18.09.2018.

Larissis and Others v. Greece, No. 23372/94, 26377/94 and 26378/94, judgement of 24.02.1998.

Leyla Sahin v. Turkey [GC], No. 44774/98, ECHR judgment of 10.11.2005.

Leyla Sahin v. Turkey, No. 44774/98, ECHR judgment of 29.06.2004.

Ligue des Musulmans de Suisse and Others v. Switzerland, No. 66274/09, decision on the admissibility of the complaint of 8.07.2011.

Lotter and Lotter v. Bulgaria, no. 39015/97, ECHR judgment of 19.05.2004.

Manoussakis and Others v. Greece, No. 18748/91, ECHR judgment of 26.09.1996.

Milanović v. Serbia, No. 44614/07, ECHR judgment of 14.12.2010.

Nolan and K. v. Russia, no. 2512/04, ECHR judgment of 12.02.2009.

Ouardiri v. Switzerland, No. 65840/09, decision on the admissibility of the complaint of 8.07.2011.

Öz v. Germany, no 32168/96, ECHR decision of 3.12.1996.

Perry v. Latvia, no. 30273/03, ECHR judgment of 8.11.2007.

R. Singh v. France, No. 27561/08, decision on the admissibility of the complaint of 30.06.2009.

Refah Partisi (The Welfare Party) and Others v. Turkey [GC], No. 41340/98, 41342/98 and 41244/98, Grand Chamber judgment of 13.02.2003.

Serif $v$ Greece, no. 38178/97, ECHR judgment of 14.12.1999.

Swami Omkarananda and Divine Light Zentrum v. Switzerland, no. 8118/77, decision on the admissibility of the complaint of 19.03.1981.

Tepeli and Others v. Turkey (dec.), No. 31876/96, decision on the admissibility of the complaint of 11.09.2001.

United Communist Party of Turkey and Others v. Turkey [GC], No. 133/1996/752/951 ECHR judgment of 30.01.1998.

\section{Secondary literature}

FALSKI J.: “Zderzenie państwa świeckiego z państwem wyznaniowym. Turecki spór o laickość." In: Państwo wyznaniowe. Doktryna, prawo i praktyka. Ed. J. SzymaneK. Warsaw 2011.

Warchalowski K.: Prawo do wolności myśli, sumienia i religii w Europejskiej Konwencji Praw Człowieka i Podstawowych Wolności. Lublin 2004.

Garlicki L.: Konwencja o Ochronie Praw Człowieka i Podstawowych Wolności. Warsaw 2011, t. 1.

Hucal M.: Wolność sumienia $i$ wyznania $w$ orzecznictwie ETPCz. Warsaw 2012.

KowALSKi M.: “Symbole religijne w przestrzeni publicznej — w poszukiwaniu standardów europejskich.” In: Prawne granice wolności sumienia i wyznania. Eds. R. Wieruszewsi, M. Wyrzykowski, L. Kondratiewa-Bryzik. Warsaw 2012. 
Michae Hucat

\section{Défis liés à l'accroissement de la diversité religieuse à la lumière de la jurisprudence de la Cour européenne des droits de l'homme}

\section{Résumé}

Les États européens ont répondu de différentes manières aux tensions liées à l'augmentation de la diversité religieuse, et les restrictions introduites ont été considérées comme appropriées lorsqu'elles relevaient de la sécurité publique et de la nécessité de protéger les autres, surtout si l'État présentait une justification crédible. A cette occasion, la jurisprudence de la Cour européenne des droits de l'homme a introduit deux notions clés pour la détermination de la présence de symboles religieux dans les lieux publics : un symbole externe fort (a powerful external symbol) et un symbole essentiellement passif (an essentially passive symbol). Une réalisation importante du Tribunal est également l'introduction du concept de "prosélytisme inapproprié » (improper proselytism). Certes, la continuation de la croissance de la diversité religieuse en Europe peut conduire à de nouveaux domaines de controverse, qui seront ensuite évalués par la Cour. Cependant, les instruments existants utilisés par la Cour, tels que l'idée de la Convention perçue comme un document vivant, la théorie de la marge d'appréciation ou l'analyse de l'existence du consensus européen, lui permettent de développer son interprétation dans ce domaine.

Mots clés : Cour européenne des droits de l'homme, diversité religieuse, symbole religieux, prosélytisme

Michae Hucae

Sfide legate all'aumento della diversità religiosa alla luce della giurisprudenza della Corte europea dei diritti dell'uomo

Abstract

Gli stati europei hanno risposto in modi diversi alle tensioni legate alla crescente diversità religiosa, e le restrizioni introdotte sono state ritenute appropriate quando dovevano garantire la sicurezza pubblica e la protezione di terzi, soprattutto se lo Stato presentava una giustificazione credibile. In questa occasione, la giurisprudenza della Corte Europea dei Diritti dell'Uomo ha introdotto due concetti chiave per determinare la presenza di simboli religiosi nei luoghi pubblici: un simbolo esterno forte (a powerful external symbol) e un simbolo essenzialmente passivo (an essentially passive symbol). Una realizzazione importante del Tribunale è anche l'introduzione del concetto di "proselitismo improprio" (improper proselytism). Naturalmente, un ulteriore aumento della diversità religiosa in Europa può portare a nuovi ambiti di controversia, che saranno poi valutati dalla Corte. Tuttavia, gli strumenti esistenti utilizzati dalla Corte, come l'idea della Convenzione in quanto un documento vivo, la teoria del margine di discrezionalità o l'analisi dell'esistenza del consenso europeo, consentono di sviluppare la sua interpretazione in questo dominio.

Parole chiave: Corte europea dei diritti dell'uomo, diversità religiosa, simbolo religioso, proselitismo. 